\title{
An Economic Analysis of Marketing of Potato from Shimla Hills of Himachal Pradesh
}

\author{
Dhiraj K. Singh ${ }^{1 *}$, N.K. Pandey ${ }^{2}$ and P. Kharumnuid ${ }^{2}$ \\ ${ }^{1}$ ICAR-Research Complex for Eastern Region, Patna-800014, Bihar, India \\ ${ }^{2}$ Division of Social Sciences, ICAR-Central Potato Research Institute, Shimla-171001, Himachal Pradesh, India \\ *Corresponding author: dhirajextension@gmail.com
}

\begin{abstract}
Potato is an important cash crop of Himachal Pradesh. Although, potato production in the state is very less, it fetches higher price than potato from plain areas due to its off seasonality. The study of potato marketing in hilly region is necessary to find out the share of profit made by farmers and other intermediaries in the marketing channel. Therefore, current study was attempted to find out marketing cost, margins, price spread and marketing efficiency of potato produced in Shimla hills. The interview schedule was used to collect primary data from 40 potato growers from Shimla and wholesalers as well as retailers from Chandigarh market. The collected data were analyzed by using suitable tools of statistics and economic measures. The findings indicated that majority of potato was sold to wholesalers at Chandigarh market through commission agent. The marketed surplus of potato was nearly 80 per cent of total produce and 15 per cent was retained by farmers for seed purpose. The average cost of marketing of 1 quintal of potato was found to be one fourth of consumer price. More than half of total marketing cost was borne by the farmer. The producers share in consumer rupees was found to be 66 per cent. The marketing efficiency was estimated to be 1.95 by Acharya and Agrawal method. Higher transportation cost and shortage of labour for post-harvest operation were major constraints. In order to reduce marketing cost borne by farmers, cooperative marketing should be initiated in Shimla hills. Farmers need to be grouped as Farmer Producer Society (FPOs) to increase their share in consumer rupees.
\end{abstract}

Keywords: Marketed surplus, Marketing channels, Marketing efficiency, Marketing margins, Potato, Price Spread, Producers' share in consumer rupees, Himachal Pradesh

Vegetables are very important component of our daily diet providing essential vitamins and minerals to the body. India is the second largest vegetable producing country in the world after China with nearly 169 million tons of vegetable production from an area of 10.1 million ha. Potato is the most popular vegetable consumed across the country in different forms. Mostly, potato is consumed as table purpose vegetable. The importance of potato among all vegetables can be estimated from the fact that potato almost contributes 27.3 per cent of total vegetable production in India. Currently, India is the second largest potato producer of the world only behind China. During the year 2016-17, India produced 48.6 million $t$ of potato from an area of 2.18 million ha with an average productivity of 22.3 t/ha (DAC\&FW, 2017).
Although, Uttar Pradesh, West Bengal, Bihar, Punjab, Madhya Pradesh and Gujarat are major states for potato production, potatoes from hilly states like Himachal Pradesh, Jammu and Kashmir, Uttarakhand and North eastern states have their own importance due to their off seasonality. Proper marketing of potato has always been a cause of concern for potato growers across the country. Potato is an important cash crop of Himachal Pradesh (HP) where it is grown during whole year at different locations as per altitude. The potato crop planted in the month of January and afterwards in HP becomes very popular due to its off-season nature and is sold in various parts of the country as Pahari Aloo which gets premium price as it is fresh and does not have sweet taste like the cold stored 
potatoes. (Pandit et al. 2010). This kharif potato from hills has been fetching 1.5 to 2 times higher price in the market as compared to cold stored potato produced under rabi season in the plains (Rana et al. 2016).

Inadequate marketing infrastructure and more number of intermediaries between producer \& consumer result in high marketing cost which lowers the farmers' profitability. The marketing of potato is a complicated activity on account of its semi-perishable nature and bulkiness. The efficient marketing of potato is necessary to increase producer's share in consumer's rupee (Johl \& Dahiya, 1999). Present study was conducted to analyze the marketing efficiency of potato produced in Shimla hills during off season.

\section{Data Base and Methodology}

Shimla district was purposively selected for this study because it is the highest potato producing district of Himachal Pradesh. As per reports, potato production in Himachal stood at 183,252 tons from an area of 18022 ha, of which, Shimla district alone contributed nearly 35\% of total production (Statistical Outline of HP-2016). Primary data was collected from 40 randomly selected potato growers from Kufri area of Shimla during SeptemberOctober, 2016. Data was also collected from 5 wholesalers and 10 retailers from Chandigarh market since most of the potatoes from Shimla were sold in Chandihgarh. A well-structured interview schedule was used for collection of data from farmers, wholesalers and retailers. Some economic tools were used to estimate marketed surplus, price spread, producer's share in consumer rupees and marketing efficiency.

Marketed surplus is the actual quantity of produce which farmer actually sell in the market irrespective of his requirements for home consumption, seed, farm needs etc. It is estimated by deducting quantity of produce consumed for home/seed purpose and loss due to spoilage from total production. Since, spoilage loss was negligible due to vicinity of market, marketed surplus was estimated by following formula:

$$
\mathrm{MS}_{\mathrm{p}}=\mathrm{Q}_{\mathrm{T}}-\left(\mathrm{Q}_{\mathrm{HC}}+\mathrm{Q}_{\mathrm{SC}}\right)
$$

Where, $\mathrm{MS}_{\mathrm{p}}=$ Marketed Surplus of Potato, $\mathrm{Q}_{\mathrm{T}}=$ Total production, $\mathrm{Q}_{\mathrm{HC}}=$ Home consumption and $\mathrm{Q}_{\mathrm{SC}}=$ Seed consumption .
Price spread is generally referred as difference between the price paid by the ultimate consumer and net price received by the producer per unit of the commodity. It helps in estimating the share of different market functionaries in the consumer's rupee and thus facilitate the understanding of efficiency of marketing channels.

Producer's Share in Consumer's Rupee was calculated with the help of the following formula.

$$
\mathrm{Ps}=(\mathrm{Fp} / \mathrm{Cp}) \times 100
$$

Where,

Ps $=$ Producerm's share in consumer rupee (percentage)

$\mathrm{Fp}=$ Farmer's net selling price

$\mathrm{Cp}=$ Consumer's price

Marketing efficiency was estimated by the Modified Measure of Marketing Efficiency (MME) developed by Acharya and Agrawal (2007) which takes into account both marketing cost and margins per unit of product marketed and farmers price.

$$
\mathrm{ME}=\mathrm{NFP} /(\mathrm{MC}+\mathrm{MM})
$$

Where, $\mathrm{ME}=$ Marketing efficiency, NFP: Net price received by farmer, $\mathrm{MC}$ : Marketing Costs and MM: Market Margins.

Simple statistical tools like mean, averages, percentages and weighted mean score were used for data analysis and interpretation.

\section{RESULTS AND DISCUSSION}

Potato is utilized as a cash crop in hills of Shimla. Therefore, most of the produce was sold to market and a small quantity of potato is retained for home consumption and for seed to be utilized in the next season. It was observed that out of total production of potato per unit area (11.94 t/ha), on an average 0.55 ton $(4.6 \%)$ was kept for home consumption and 1.8 ton $(15.2 \%)$ was retained for seed purpose (Table 1).

Therefore, marketed surplus of potato was high to the extent of 80 per cent. Farm retention was maximum for medium farmers $(23.96 \%)$ followed by large and small category of farmers. However, Small farmers had maximum marketed surplus $(82.26 \%)$ followed by large farmers $(80.2 \%)$ and 
medium farmers $(76.06 \%)$. This may be due to need for higher income for small farmers since more marketed surplus would give them more income. These results are in confirmation with the findings of Kaur and Sidhu (2015) who studied the marketing of potato in Jalandhar district of Punjab.

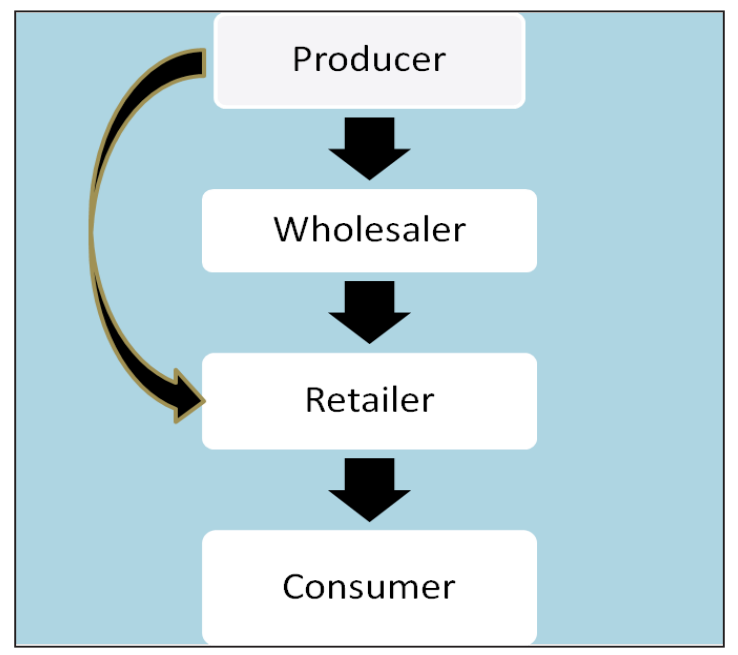

Table 1: Marketed surplus of potato for different farm sizes (t/ha)

\begin{tabular}{|c|c|c|c|c|c|}
\hline \multirow{2}{*}{$\begin{array}{l}\text { Sl. } \\
\text { No. }\end{array}$} & \multirow{2}{*}{$\begin{array}{l}\text { Particulars (per } \\
\text { ha basis) }\end{array}$} & \multicolumn{3}{|c|}{ Category of farmers } & \multirow{2}{*}{$\begin{array}{l}\text { Overall } \\
(\mathrm{N}=40)\end{array}$} \\
\hline & & $\begin{array}{l}\text { Small } \\
(\mathrm{n}=20)\end{array}$ & $\begin{array}{c}\text { Medium } \\
(\mathrm{n}=12)\end{array}$ & $\begin{array}{l}\text { Large } \\
(\mathrm{n}=8)\end{array}$ & \\
\hline 1 & Total Pro & $\begin{array}{c}10.86 \\
(100.00)\end{array}$ & $\begin{array}{c}12.05 \\
(100.00)\end{array}$ & $\begin{array}{c}14.04 \\
(100.00)\end{array}$ & $\begin{array}{c}11.94 \\
(100.00)\end{array}$ \\
\hline 2 & Quantity consume & ed of farn & & & \\
\hline (a) & $\begin{array}{c}\text { Home } \\
\text { consumption }\end{array}$ & $\begin{array}{c}0.57 \\
(5.24)\end{array}$ & $\begin{array}{l}0.625 \\
(5.19)\end{array}$ & $\begin{array}{l}0.404 \\
(2.77)\end{array}$ & $\begin{array}{l}0.548 \\
(4.59)\end{array}$ \\
\hline (b) & Kept for seed & $\begin{array}{l}1.357 \\
(12.5)\end{array}$ & $\begin{array}{c}2.26 \\
(18.75)\end{array}$ & $\begin{array}{l}2.205 \\
(15.7)\end{array}$ & $\begin{array}{c}1.815 \\
(15.20)\end{array}$ \\
\hline 3 & $\begin{array}{c}\text { Marketed } \\
\text { Surplus }=(1-2)\end{array}$ & $\begin{array}{c}8.933 \\
(82.26)\end{array}$ & $\begin{array}{r}9.165 \\
(76.06)\end{array}$ & $\begin{array}{l}11.431 \\
(81.53)\end{array}$ & $\begin{array}{c}9.577 \\
(80.21)\end{array}$ \\
\hline
\end{tabular}

Note: Figure in parentheses indicate percentage

Table 2: The disposal pattern of marketed surplus of potato

\begin{tabular}{ccccc}
\hline S1 & Particulars & \multicolumn{2}{c}{ Intermediaries } & All \\
\cline { 3 - 4 } No. & & Retailer & Wholesaler & functionaries \\
\hline 1 & Quantity sold & 423 & 658 & $1081(100.00)$ \\
& (qt) & $(39.13)$ & $(60.87)$ & \\
2 & Price per & 1820 & 1705.5 & 1750.3 \\
& quintal (₹) & & & \\
3 & Values (₹) & 769860 & 1122219 & 1892079 \\
& & $(40.69)$ & $(59.31)$ & $(100.00)$ \\
\hline
\end{tabular}

Note: Figure in parentheses indicate percentage
Farmers generally sell their produce in those markets where they can get higher price. Farmer's decision regarding agency of sale also depends on mode of transport available, distance of market, transportation cost and economic condition of farmers. Marketing channels shows that how the produce move from producer to ultimate consumer and who are the intermediaries involved in this movement.

In the study area, two marketing channels were most commonly found for potato marketing. These are Channel I: Producer - Retailer - Consumer and Channel II: Producer - Wholesaler - RetailerConsumer. Out of these Channel II was the most commonly used marketing channel in Shimla, since majority of produce was sold through wholesalers of Chandigarh market. This was due to higher price realisation and less transport cost for potato. Most of the farmers hired a common truck and send their produce in group which saved their transport cost. It can be observed from Table 2 that nearly 60 per cent of total marketed surplus was sold through wholesalers to Chandigarh market and $40 \%$ was sold directly to retailers of the local market in Shimla. It is interesting to note that a significant quantity of potato was directly sold to retailer because of higher price realization i.e. Rs 1820 per quintal. Similar results were observed by Jadav et al. in their study of supply chain of potato in middle Gujarat.

Majority of potato growers in Shimla sold their produce to the wholesale market of Chandigarh. From there, potatoes were sold to retailers and finally to consumers at a higher price. In this process, the producer as well as wholesalers and retailers had to borne the cost involved in different marketing functions like grading, packaging, transportation, handling charges etc. The marketing cost incurred by producer, wholesalers and retailers are given in Table 3.

It is evident from Table 3 that the highest marketing cost per quintal of potato was incurred by producer himself (₹ 309.6/qt) followed by wholesaler (₹ 153.4/ qt) and retailer (₹ 79.15/qt). It was due to higher transportation cost incurred by farmer. The farmer has to hire truck to send the potatoes from Shimla hills to Chandigarh which costed them nearly ₹ 200 per quintal including loading and unloading charges. 
Table 3: Cost incurred by different marketing functionaries and price spread in potato

\begin{tabular}{|c|c|c|c|}
\hline $\begin{array}{l}\text { Sl. } \\
\text { No. }\end{array}$ & Particulars & $\begin{array}{l}\text { ₹ Per } \\
\text { qtl. }\end{array}$ & $\begin{array}{c}\text { \% share in } \\
\text { consumer's price }\end{array}$ \\
\hline 1. & $\begin{array}{l}\text { Producer's sale price/ } \\
\text { wholesaler's purchase } \\
\text { price }\end{array}$ & 1705.5 & 80.82 \\
\hline 2. & $\begin{array}{l}\text { Cost incurred by the } \\
\text { producer }\end{array}$ & 309.6 & 14.67 \\
\hline (i) & $\begin{array}{l}\text { Grading, filling, stitching } \\
\text { etc. }\end{array}$ & 65.0 & 3.08 \\
\hline (ii) & Cost of gunny bag & 35.4 & 1.68 \\
\hline (iii) & $\begin{array}{l}\text { Loading and } \\
\text { transportation cost }\end{array}$ & 189.2 & 8.96 \\
\hline (iv) & Unloading charges & 20.0 & 0.95 \\
\hline 3 & $\begin{array}{l}\text { Net price received by the } \\
\text { producer }\end{array}$ & 1395.9 & 66.15 \\
\hline 4 & $\begin{array}{l}\text { Cost incurred by the } \\
\text { wholesaler }\end{array}$ & 153.4 & 7.27 \\
\hline (i) & Market fee @ 2\% & 34.1 & 1.61 \\
\hline (ii) & $\begin{array}{l}\text { Rural development fund } \\
\text { @ } 2 \%\end{array}$ & 34.1 & 1.61 \\
\hline (iii) & $\begin{array}{l}\text { Commission to the } \\
\text { commission agent @ 5\% }\end{array}$ & 85.2 & 4.04 \\
\hline 5 & Margin of the wholesaler & 46.1 & 2.18 \\
\hline 6 & $\begin{array}{l}\text { Wholesaler's sale price/ } \\
\text { retailer's purchase price }\end{array}$ & 1905.0 & 90.28 \\
\hline 7 & $\begin{array}{l}\text { Cost incurred by the } \\
\text { retailer }\end{array}$ & 79.15 & 3.75 \\
\hline (i) & Transportation cost & 7.0 & 0.33 \\
\hline (ii) & Packing cost & 15.0 & 0.71 \\
\hline (iii) & $\begin{array}{l}\text { Loss, wastage and } \\
\text { spoilage @ 3\% }\end{array}$ & 57.15 & 2.71 \\
\hline 8 & Margin of the retailer & 125.85 & 5.96 \\
\hline 9 & $\begin{array}{l}\text { Retailer's sale price/ } \\
\text { consumer's purchase } \\
\text { price }\end{array}$ & 2110 & 100.00 \\
\hline 10 & Price Spread (9-3) & 714.1 & 33.8 \\
\hline
\end{tabular}

Marketing costs of wholesalers consisted of commission agent charges, market fee and rural development fee. Wastage and spoilage losses of potato during marketing were borne by retailer. It can also be observed that marketing margin for retailer (₹ 125.8/qt) was nearly three times higher than wholesalers. This was mostly because potatoes from hills were liked by consumers and therefore it was sold to them by retailers at a very high price of ₹ $2110 /$ qt.

The price spread in the marketing channel was estimated to be 33.8 per cent which implies that the producers shared 66.2 per cent of the price paid by the consumer. The margin enjoyed by wholesaler was only 2.18 per cent of consumer price which was much lower than that of retailer (5.96\%).

Marketing efficiency is nothing but the degree of market performance. It is generally assessed by the size of share which producer obtains in the price paid by consumer. The marketing efficiency for potato was worked out by using formula given by Acharya and Agrawal (2007) and results are presented in Table 4.

Table 4: Marketing efficiency of potato from hills at Chandigarh market (₹/qt)

\begin{tabular}{clc}
\hline $\begin{array}{l}\text { S1. } \\
\text { No. }\end{array}$ & Particulars & Value \\
\hline 1 & $\begin{array}{l}\text { Consumer's price/Retail price of potato } \\
\text { (₹/qt) }\end{array}$ & 2110 \\
2 & Total Marketing cost (₹/qt) & 542.15 \\
3 & Marketing margins (₹/qt) & 171.95 \\
4 & Net price received by producer (₹/qt) & 1395.9 \\
5 & Marketing efficiency by Acharya's & 1.95 \\
& method \\
\hline
\end{tabular}

The profitability of the crop is guiding factor for resource allocation, which apart from production efficiency depends on the price received by the producer in terms of consumer rupees (Sidhu et al. 2011). It can be seen that potato growers received a net price of ₹ 1395.9/qt which constitutes nearly two third of consumer price in the selected marketing channel. It implies that they are getting a good share in consumer rupees. The average cost of potato marketing was ₹ 542.15 per quintal and total marketing margin was ₹ 171.95 spread among wholesalers and retailers. Thus, marketing cost was 25.7 per cent of consumer price. This finding is in confirmation with the findings of Jadav et al (2011) in which they concluded that marketing cost incurred by various intermediaries was $26.3 \%$ of consumer price. The marketing efficiency was estimated to be more than unity i.e. 1.95 which implies that this channel was efficient. This may be the reason; farmers prefer to sell their potatoes to wholesalers at Chandigarh.

Constraints faced by potato growers was studied in terms of its extent of severity and weighted mean score was calculated for each constraints (Table 5). The results revealed that "Higher cost of 
Table 5: Constraints perceived by farmers during marketing of potato from Shimla $(N=40)$

\begin{tabular}{|c|c|c|c|c|c|}
\hline \multirow{2}{*}{$\begin{array}{l}\text { Sl. } \\
\text { No. }\end{array}$} & \multirow[t]{2}{*}{ Constraints } & \multicolumn{3}{|c|}{ Extent of severity (frequency) } & \multirow{2}{*}{$\begin{array}{l}\text { Weighted mean score } \\
\text { (WMS) }\end{array}$} \\
\hline & & $\begin{array}{c}\text { Severe } \\
(\text { Weight }=3)\end{array}$ & $\begin{array}{c}\text { Moderate } \\
(\text { Weight }=2)\end{array}$ & $\begin{array}{l}\text { Negligible } \\
(\text { Weight }=1)\end{array}$ & \\
\hline 1 & $\begin{array}{l}\text { Shortage of labour for post- } \\
\text { harvest operations }\end{array}$ & 14 & 4 & 22 & 24.0 \\
\hline 2 & $\begin{array}{l}\text { Inadequate capacity of cold } \\
\text { stores }\end{array}$ & 4 & 8 & 28 & 18.6 \\
\hline 3 & Glut in the local market & 0 & 12 & 28 & 17.3 \\
\hline 4 & Higher cost of transportation & 12 & 18 & 10 & 27.3 \\
\hline 5 & Loss during transport to market & 0 & 4 & 36 & 14.6 \\
\hline 6 & Higher fluctuation in price & 2 & 26 & 12 & 23.3 \\
\hline 7 & $\begin{array}{l}\text { Higher involvement of } \\
\text { middlemen }\end{array}$ & 0 & 14 & 26 & 18.0 \\
\hline
\end{tabular}

transportation" with weighted mean score of 27.3 was the most severe constraint faced by farmers followed by "Shortage of labour for post-harvest operations" (WMS=24) and "Higher fluctuation in price" (WMS=23.3). Being hilly region, transport cost was towards higher side for farmers. The fact is supplemented by data that nearly one third of total marketing cost consisted of transportation and loading cost incurred by farmers.

Moreover, for handling, grading and packing, a lot of labour is required which was in shortage at Shimla hills. "Inadequate capacity of cold stores" and "Higher involvement of middlemen" were other major constraints faced by farmers. Inadequate number of cold store is not a major problem, since temperature during harvesting season and postharvest operation never goes beyond $25^{\circ} \mathrm{C}$.

\section{CONCLUSION}

This study has examined the marketing costs, margins and price spread in potato in Shimla at Chandigarh market. Being a cash crop of Shimla, marketed surplus of potato was nearly 80 per cent. It could have been higher if 15.2 per cent of produce may not have retained by farmers for using as seed in next generation. Most of the produce $(60.9 \%)$ was sold through wholesalers and retailers at Chandigarh market because of higher price as compared to local market. Therefore, Producer-wholesaler-retailer-consumer was the most common marketing channel in study area. Most of the marketing cost was incurred by farmers which need to be reduced so that producer share in consumer rupees could be increased. The finding showed that margin of retailer was more than double that of wholesaler. But wastage charges at retailer level was quite high at 3 per cent which must be reduced by proper grading, packaging and storage. The consumer price received at Chandigarh was ₹ 2110 per quintal which is high as compared to prices of potato in other markets. This was due to off season nature of potatoes from hills which gave farmer 66 per cent share in consumer rupees. Higher cost of transport and labour shortage were major constraints faced by potato growers. Cooperative marketing can reduce the transport cost significantly. Use of machineries for grading, packaging can solve the problem of labour shortage in this area.

\section{REFERENCES}

Acharya, S.S. and Agarwal, N.L. 2007. Agricultural Marketing in India, Oxford and IBH Publishing Co., New Delhi, pp. 385-417.

Department of Agriculture and Farmers Welfare. 2017. Ministry of Agriculture and Farmers Welfare, Govt. of India (available from http://www.agricoop.nic.in/ sites/ default/files/2016-17\%28Final\%29.pdf accessed on $10^{\text {th }}$ January, 2018).

Jadav, K.S., Leua, A.K. and Darji, V.B. 2011. Economic analysis of supply chain of fresh potato in middle Gujarat, Indian Journal of Agricultural Research, 45(4): 266-274. 
Johl, S.S. and Dahiya, P.S. 1999. Potato marketing with special reference to storage and processing in the world, Abstracts, Global conference on potato, New Delhi: 51-53.

Kaur, A. and Sidhu, M.S. 2015. Marketing of potato in Jalandhar district of Punjab, Indian J. Econ. Dev., 11(4): 8263-832.

Pandit, A., Kumar A., Rana, .RK., Pandey, N.K. and Kumar, N.R. 2010. A study on socio-economic profile of potato farmers: comparison of irrigated and rainfed conditions in Himachal Pradesh, Potato Journal, 37(1-2): 56-63.
Rana, R.K., Kumar, S. and Chaudhary, K.R. 2016. Kharif potato production in India - Overcoming the lapses in its marketing, Indian Farming, 66(4): 13-15.

Sidhu, R.S., Sidhu, M.S. and Singh, J.M. 2011. Marketing efficiency of green peas under different supply chains in Punjab, Agricultural Economics Research Review, 24: 267-273. 